Zeszyty Naukowe Politechniki Częstochowskiej

Zarządzanie Nr 28 t. 1 (2017) s. 130-146

dostępne na: http://www.zim.pcz.pl/znwz

\title{
PARTNERSTWO PUBLICZNO-PRYWATNE JAKO TREND ZARZĄDZANIA ZADANIAMI PUBLICZNYMI W POLSCE W LATACH 2009-2016
}

\author{
Olga Ławińska, Karina Kowalczyk \\ Politechnika Częstochowska \\ Wydział Zarządzania
}

\begin{abstract}
Streszczenie: Partnerstwo publiczno-prywatne (PPP) stanowi jedną z form współpracy podmiotów publicznych, dzięki której mogą one skutecznie zarządzać zadaniami publicznymi. Celem niniejszego artykułu jest analiza i ocena współpracy opartej na partnerstwie publiczno-prywatnym w Polsce w latach 2009-2016 oraz prezentacja przykładowego zastosowania tej formuły w infrastrukturze transportowej. Wyniki badań wskazują, iż w Polsce w latach 2009-2016 wzrosło zainteresowanie współpracą między sektorem publicznym a prywatnym, jednak był to wzrost powolny. Analizując PPP w Polsce, można zauważyć dominację projektów o małej wartości. Zaprezentowane przykłady współpracy w formie koncesji w obszarze infrastruktury transportowej (komunikacji miejskiej) potwierdzają zalety realizacji inwestycji infrastrukturalnych na zasadach partnerstwa publiczno-prywatnego.
\end{abstract}

Słowa kluczowe: koncesja, partnerstwo publiczno-prywatne, zadania publiczne, zarządzanie

DOI: $10.17512 /$ znpcz.2017.4.1.11

\section{Wprowadzenie}

W ostatnich latach można zauważyć zwiększenie zainteresowania długoterminową współpracą pomiędzy podmiotami sektora publicznego oraz prywatnego. Współdziałanie to określane jest jako partnerstwo publiczno-prywatne (stosowany skrót PPP). Podejmowane jest celem uzyskania korzyści dla obu stron, w tym zaspokojenia potrzeb społecznych oraz określonych celów komercyjnych, wliczając w to np. określoną stopę zwrotu, uwzględniając podział ryzyka.

Obserwując współpracę pomiędzy partnerami publicznymi i prywatnymi, można dostrzec rozbieżności w zakresie jej rozwoju w różnych krajach. W Polsce rozwój partnerstwa publiczno-prywatnego $\mathrm{w}$ początkowym okresie następował bardzo wolno. Najpierw regulowane było ono przez Ustawę z dnia 28 lipca 2005 r. o partnerstwie publiczno-prywatnym, jak również przez przepisy prawa zamówień publicznych, w części, która od 2004 roku dotyczyła koncesji na roboty budowlane. Mimo wprowadzonych regulacji wystąpił brak zainteresowania współpracą w tej formule - tylko jedno przedsięwzięcie. W 2008 roku wprowadzono nowe regulacje dotyczące partnerstwa publiczno-prywatnego (Ustawa z dnia 19 grudnia $2008 \mathrm{r}$. o partnerstwie publiczno-prywatnym). Prócz tego regulowane jest ono Ustawą z dnia 21 października 2016 r. o koncesji na roboty budowlane lub usługi, jak również Ustawą z dnia 29 stycznia 2004 r. - Prawo zamówień publicznych (por.: Raport 
rynku PPP... 2013, s. 4). Wprowadzone nowe regulacje spowodowały większe zainteresowanie partnerstwem publiczno-prywatnym ze strony różnych podmiotów publicznych, a także prywatnych. Obecnie w Polsce wzrasta nacisk na większe wykorzystywanie przedstawionej formuły współpracy.

$\mathrm{Z}$ uwagi na konieczność podejmowania wielu inwestycji przez podmioty publiczne, a także wielokrotne występowanie różnicy między możliwościami finansowanymi tychże podmiotów a potrzebami inwestycyjnymi, koniecznym staje się rozważenie różnych form finansowania (Lukomska-Szarek 2011, s. 76-78), w tym uwzględnienie współpracy opartej na partnerstwie publiczno-prywatnym. Ważnym staje się więc pokazanie, jak wygląda rozwój tej formy w Polsce, a przede wszystkim dobrych praktyk w tym zakresie, które mogą stać się inspiracją do podejmowania takich działań. Przed podjęciem decyzji o PPP należy dokładnie przeanalizować liczne korzyści wynikające z takiej współpracy, a także występowanie zagrożeń.

Celem niniejszego artykułu jest analiza i ocena współpracy opartej na partnerstwie publiczno-prywatnym w Polsce w latach 2009-2016 oraz prezentacja przykładowego zastosowania tej formuły w infrastrukturze transportowej. Metodami badawczymi zastosowanymi w tym artykule są: studia literaturowe, analiza danych zastanych oraz case study.

\section{Pojecie i zakres PPP}

Pojęcia „partnerstwo publiczno-prywatne” po raz pierwszy użyto w Stanach Zjednoczonych w latach 50. XX wieku dla określenia wspólnego finansowania programów edukacyjnych przez sektory publiczny i prywatny. $Z$ czasem określenie to, łączące dualizm finansowania, weszło do obiegu powszechnego - używano go np. w czasie organizowania wspólnych działań przez rządy, agencje pomocowe czy sektor prywatny $\mathrm{w}$ walce $\mathrm{z}$ AIDS, malarią oraz innymi chorobami o zasięgu światowym (Mikołajczyk 2010, s. 110). Partnerstwo sektora publicznego z sektorem prywatnym jest dynamicznie rozwijającą się formą finansowania zadań publicznych w Europie i na świecie. Regulacje prawne partnerstwa publiczno-prywatnego (PPP) w Europie są stosunkowo nowe, obowiązują od blisko 25 lat. Formuła PPP może być sposobem na rozwiązanie problemów inwestycyjnych gospodarek narodowych. Zaangażowanie kapitału prywatnego przyczynia się do zaspokajania stale rosnących oczekiwań społeczeństwa w zakresie ilości i standardu świadczenia usług na poziomie samorządu lokalnego oraz w odniesieniu do innych struktur państwa (Łakomy 2012, s. 65-66).

Ch. Skelcher stwierdza, iż PPP łączy zasoby rządu z podmiotami prywatnymi dla realizacji celów społecznych. Formy PPP to zawieranie umów na świadczenie usług, zarządzanie przedsiębiorstwem użyteczności publicznej oraz projektowanie organizacji hybrydowych w celu podziału ryzyka i współdziałania między administracją rządową a podmiotami prywatnymi. Jasność koncepcji jest warunkiem wstępnym dyskusji nad partnerstwem publiczno-prywatnym. Terminy: ,publiczny”, ,prywatny” i „partnerstwo" są w literaturze szeroko opracowane, indywidualnie i zbiorowo, a ich znaczenie uzależnione jest od kontekstu. W Europie Zachodniej wyrażenie ,partnerstwo publiczno-prywatne" dotyczy konkretnie mechanizmu rozproszenia ryzyka, 
uzyskania finansowania pozabudżetowego oraz zwiększenia innowacyjności w zakresie projektowania, budowy i eksploatacji projektów opartych na infrastrukturze. Ujednolicona interpretacja w USA jest szersza i obejmuje różne instrumenty, za pomocą których rząd angażuje się w sprawy biznesowe i niedochodowe, w realizację celów polityki publicznej (Skelcher 2005, s. 347-348). W niniejszym opracowaniu użyto pojęcia „PPP” w ogólnym sensie, aby odnieść się do sposobów, w jaki rząd i podmioty prywatne współpracują $\mathrm{w}$ dążeniu do realizacji celów społecznych.

W literaturze często cytowana jest definicja The National Council for Public-Private Partnerships. Zgodnie z tym ujęciem ,partnerstwo publiczno-prywatne to oparte na umowie porozumienie między jednostką publiczną i podmiotem prywatnym o charakterze komercyjnym. Dzięki temu porozumieniu umiejętności i zasoby każdego z sektorów wykorzystywane są przy dostarczaniu usług odbiorcom i udostępnianiu obiektów użytkownikom" (Rutkowski 2010, s. 31). Pojęcie to można rozpatrywać w sposób bardziej ogólny. PPP jest akceptowaną przez Komisję Europejską formą współpracy przedsiębiorczości prywatnej z sektorem publicznym na wszystkich szczeblach. Komisja Europejska nie narzuca sztywnych zaleceń co do modelu organizacyjnego PPP. Podkreśla jedynie, iż ogólnym założeniem tego rodzaju przedsięwzięć jest stworzenie takiego związku między podmiotami sektorów publicznego i prywatnego, by ryzyko ponosiła ta strona, która potrafi nim najefektywniej zarządzać pod względem kosztów, oraz aby każda ze stron mogła najlepiej realizować postawione sobie cele (Gawroński 2010, s. 123-124).

Od 2005 roku partnerstwo publiczno-prywatne w Polsce to prawnie uregulowany instrument do realizacji zadań publicznych. Zatem gmina może samodzielnie zarządzać zadaniami publicznymi bądź wykorzystać formułę partnerstwa publiczno-prywatnego. Obecnie obowiązują dwie ustawy regulujące PPP: ustawa o partnerstwie publiczno-prywatnym oraz ustawa o koncesji na roboty budowlane lub usługi. Ustawa o partnerstwie publiczno-prywatnym nie definiuje wprost tytułowego partnerstwa, ale poprzez wskazanie cech umowy PPP. Ustawodawca w art. 1 określa, że przedmiotem partnerstwa publiczno-prywatnego jest wspólne realizowanie przez podmiot publiczny oraz podmiot prywatny (gdzie partner prywatny to przedsiębiorca lub przedsiębiorca zagraniczny) przedsięwzięć opartych na podziale zadań i ryzyka między te podmioty. $Z$ kolei ustawa o koncesji na roboty budowlane lub usługi definiuje współpracę podmiotu publicznego (koncesjodawcy) z partnerem prywatnym (koncesjonariuszem). W ustawie akcentowana jest wzajemna współpraca obu sektorów przy realizacji zadania publicznego. Koncesjonariusz zobowiązuje się do wykonania przedsięwzięcia (koncesji) za wynagrodzeniem, osiągając zakładaną korzyść, jednocześnie przejmując na siebie ryzyko realizacji inwestycji.

W odniesieniu do przedsięwzięć infrastrukturalnych w krajach Unii Europejskiej preferuje się przede wszystkim system koncesyjny oraz umowy typu BOT (Build Operate - Transfer) i DBFO (Design - Build - Finance - Operate) (Zagożdżon 2004, s. 42-43). Charakterystykę powyższych form finansowania inwestycji infrastrukturalnych zawiera Tabela 1.

Tabela 1. Formy organizacyjne partnerstwa publiczno-prywatnego dla inwestycji infrastrukturalnych 


\begin{tabular}{|c|c|c|}
\hline Umowa typu BOT & Umowa typu DBFO & Koncesja \\
\hline \multicolumn{3}{|c|}{ 1. Określenie zakresu } \\
\hline $\begin{array}{l}\text { Obejmuje projekt tech- } \\
\text { niczny, budowę i eksploata- } \\
\text { cję } \\
\text { obiektu na określony czas, } \\
\text { po upływie którego jest on } \\
\text { zwracany do sektora } \\
\text { publicznego. }\end{array}$ & $\begin{array}{l}\text { Dotyczy realizacji projektu } \\
\text { technicznego, budowy, } \\
\text { eksploatacji i finansowania } \\
\text { obiektu przez określony } \\
\text { czas, po którym obiekt jest } \\
\text { przekazywany do sektora } \\
\text { publicznego. }\end{array}$ & $\begin{array}{l}\text { Jest kontraktem z inwestorem } \\
\text { prywatnym na projekt } \\
\text { techniczny, budowę, } \\
\text { eksploatację i finansowanie } \\
\text { obiektu na określony czas, } \\
\text { po którym obiekt jest } \\
\text { przekazywany do sektora } \\
\text { publicznego, ale strona } \\
\text { prywatna odzyskuje } \\
\text { poniesione koszty z opłat } \\
\text { użytkowników. }\end{array}$ \\
\hline \multicolumn{3}{|c|}{ 2. Cechy charakterystyczne } \\
\hline $\begin{array}{l}\text { Przedsięwzięcie jest } \\
\text { finansowane przez sektor } \\
\text { publiczny, pozostaje jego } \\
\text { własnością przez czas } \\
\text { trwania umowy. Władze pu- } \\
\text { bliczne koncentrują się tylko } \\
\text { na odpowiedzialności finan- } \\
\text { sowej. Następuje } \\
\text { przeniesienie ryzyka na } \\
\text { sektor prywatny. Promuje } \\
\text { innowacje sektora } \\
\text { prywatnego. Kompleksowy } \\
\text { i złożony typ umów może } \\
\text { przedłużać proces przetargu. } \\
\text { Wymaga systemów } \\
\text { zarządzania projektem i mo- } \\
\text { nitorowania } \\
\text { efektywności. Nie przyciąga } \\
\text { kapitału prywatnego } \\
\text { i zobowiązuje sektor } \\
\text { publiczny do } \\
\text { długoterminowego } \\
\text { finansowania. }\end{array}$ & $\begin{array}{l}\text { Obiekt jest własnością } \\
\text { sektora prywatnego na czas } \\
\text { kontraktu, a zwrot kosztów } \\
\text { inwestycji następuje przez } \\
\text { dotacje publiczne. } \\
\text { Głównym mechanizmem } \\
\text { efektywnościowym jest } \\
\text { wykorzystanie finansów pry- } \\
\text { watnych i przeniesienie ry- } \\
\text { zyka na sektor prywatny. } \\
\text { Jest odpowiedni dla } \\
\text { projektów o dużej części } \\
\text { operacyjnej. Umowy mogą } \\
\text { być bardziej kompleksowe } \\
\text { i proces przetargu może } \\
\text { trwać dłużej niż dla umów } \\
\text { BOT. Wymaga systemów } \\
\text { zarządzania projektem i mo- } \\
\text { nitorowania } \\
\text { efektywności. } \\
\text { Przyciąga kapitał prywatny. }\end{array}$ & $\begin{array}{l}\text { Głównym mechanizmem } \\
\text { efektywnościowym jest } \\
\text { zasada: zanieczyszczający } \\
\text { płaci oraz wykorzystanie ka- } \\
\text { pitału prywatnego i przenie- } \\
\text { sienie ryzyka na sektor pry- } \\
\text { watny. } \\
\text { Jest odpowiednia, gdy } \\
\text { istnieje możliwość } \\
\text { wprowadzenia opłat od } \\
\text { użytkowników. Jest } \\
\text { szczególnie korzystna dla } \\
\text { projektów dotyczących dróg } \\
\text { publicznych. Może nie być } \\
\text { akceptowalna pod względem } \\
\text { politycznym. Wymaga } \\
\text { efektywnego zarządzania al- } \\
\text { ternatywami i substytutami, } \\
\text { np. alternatywnymi } \\
\text { połączeniami drogowymi. }\end{array}$ \\
\hline
\end{tabular}

Źródło: Opracowanie własne na podstawie (Zagożdżon 2004, s. 43-44)

Doświadczenia wielu krajów europejskich wskazują, że realizacja inwestycji infrastrukturalnych w formule PPP jest znacznie tańsza niż inwestycja w modelu tradycyjnym. Partnerstwo publiczno-prywatne nabiera szczególnego znaczenia obecnie, gdy przypisywane są kolejne zadania publiczne samorządom terytorialnym i należy tak nimi zarządzać, aby zmniejszyć deficyt budżetowy. W formule partnerstwa publiczno-prywatnego odpowiedzialność narzucona przepisami prawa jest do- 
meną władzy publicznej. Główna przewaga modelu PPP nad tradycyjnymi sposobami finansowania dotyczy podziału ryzyka oraz zasady opisywanej jako wartość dodana, która oparta jest na założeniu, że udział sektora prywatnego zwiększa efektywność oraz przynosi konkretne korzyści, które przekraczają zazwyczaj wyższe koszty finansowania projektów PPP (Łakomy 2012, s. 68-69). W Tabeli 2 przedstawiono korzyści płynące z zastosowania formuły PPP.

Tabela 2. Korzyści z zastosowania partnerstwa publiczno-prywatnego

\begin{tabular}{|l|l|}
\hline \multicolumn{1}{|c|}{ Korzyści dla sektora publicznego } & Korzyści dla sektora prywatnego \\
\hline - szybsze wdrażanie projektów & - stabilny, długoterminowy \\
- zdynamizowanie procesu rozwoju & kontrakt \\
infrastruktury & - niezależność od rocznego \\
- wyższa jakość świadczonych usług & budżetu sektora publicznego \\
- wzrost innowacyjności w dostarczaniu & - elastyczność w ustaleniu \\
usług & specyfikacji produktu \\
- redukcja całkowitych kosztów projektu oraz & końcowego lub usługi \\
efektywniejsze wykorzystanie pieniędzy & - bodźce do osiągnięcia dobrych \\
publicznych & wyników i dostarczenia usług \\
- budowa zaufania publicznego & wysokiej jakości \\
- wykorzystanie doświadczenia i umiejętności & - możliwość generowania \\
sektora prywatnego & dodatkowych przychodów od \\
- wzrost wpływów budżetowych z tytułu & stron trzecich (np. przy \\
płaconych podatków i opłat przez operatora & zarządzaniu budynkiem, \\
prywatnego & wynajęcie powierzchni \\
- ograniczenie wpływów politycznych na & użytkowych) \\
decyzje inwestycyjne i eksploatacyjne & - okazja do komercyjnego \\
- oszczędności w budżecie (odciążenie sektora & wykorzystania innowacji \\
publicznego od kosztów inwestycyjnych) & \\
\hline
\end{tabular}

Źródło: (Łakomy 2012, s. 71)

Partnerstwo publiczno-prywatne zapewnia przede wszystkim korzyści finansowe. Przedsięwzięcia takie pozwalają władzom publicznym na rozdzielenie kosztów inwestycji i płacenie wyłącznie za świadczone usługi. Ta elastyczność i uzyskane oszczędności przewyższają zwykle ewentualne wyższe koszty pozyskania finansowania. Przy ograniczonych własnych możliwościach finansowych i konieczności realizacji niezbędnych inwestycji infrastrukturalnych PPP może pozytywnie wpłynąc na ich szybszą i bardziej efektywną realizację oraz sprawniejsze zarządzanie zadaniami publicznymi (Ławińska 2011, s. 54).

K. Brzozowska (Brzozowska 2006) wskazuje z kolei możliwe ograniczenia i wady partnerstwa publiczno-prywatnego:

- ograniczenie wpływu samorządu lokalnego na wybór inwestycji;

- wzrost opłat za korzystanie z obiektów infrastruktury;

- osłabienie pozycji negocjacji władz publicznych; 
- wysokie koszty transakcyjne (koszty wynajmu doradców prawnych, technicznych, finansowych);

- obniżenie poziomu świadczonych usług;

- ograniczenie dostępu do usług;

- utrata miejsc pracy dla pracowników sektora publicznego;

- ograniczenie wpływu administracji publicznej na działania eksploatacyjne prywatnego operatora, jeśli popyt na usługi będzie niższy od prognozowanego;

- podwyższanie poziomu opłat przez operatora prywatnego w ramach zasady swobody ustalania cen.

W literaturze wskazuje się na 3 kluczowe grupy efektów z realizacji PPP: efekty bezpośrednie i kreacja wiedzy (po stronie sektora publicznego) oraz efekty społeczne (dotyczą beneficjentów projektu). Efekty bezpośrednie to nabywanie zasobów i usprawnienie zarządzania w organizacjach publicznych. Kreacja wiedzy oznacza uczenie się organizacji publicznej, przepływ know-how i innowacji. Efekty społeczne to wymierne korzyści dla osób korzystających z usług publicznych, także jako efekty zewnętrzne (Kołodziej-Hajto 2015, s. 55).

Reasumując - gmina ma do realizacji wiele różnych zadań publicznych, które może wykonywać samodzielnie lub przy współpracy innych podmiotów, np. prywatnych. Wiele zadań publicznych można byłoby sprawniej realizować dzięki wykorzystaniu kapitału finansowego, wiedzy i doświadczenia w zarządzaniu i organizacji podmiotów prywatnych. Oprócz przedstawionych korzyści, z uwagi na możliwość wystąpienia różnych zagrożeń, może wystąpić sytuacja, w której założone cele nie zostaną osiągnięte. Dlatego przed podjęciem decyzji o PPP gminy powinny dokonać dokładnych analiz zalet i wad wynikających z takiej współpracy.

\section{Partnerstwo publiczno-prywatne w Polsce w latach 2009-2016}

W Polsce, jak już wyżej wskazano, można zauważyć stopniowy rozwój współpracy opartej na formule partnerstwa publiczno-prywatnego. W okresie od 2005 do 2008 roku podpisano tylko jedną umowę w ramach PPP, natomiast w kolejnych latach podpisywano coraz więcej umów oraz zgłaszano coraz więcej postępowań w tym zakresie. Poniżej przedstawiono analizę współdziałania podmiotów publicznych z prywatnymi w ramach PPP w okresie od roku 2009 do 2016. Do analizy wykorzystano dane opublikowane w raporcie pt. Analiza rynku PPP za okres od 2009 r. do 31 grudnia 2016 r.

Analizie poddano dane dotyczące „,wszystkich wszczętych postępowań”1, ,realnych projektów"2, zawartych umów w ramach partnerstwa publiczno-prywatnego. Zostały one podzielone $\mathrm{z}$ uwzględnieniem poniższych kryteriów:

\footnotetext{
${ }^{1}$ „Wszystkie wszczęte postępowania” - dotyczy wszystkich ogłoszonych postępowań, w tym zarówno tych, które zostały ogłoszone jeden raz lub kilka razy.

${ }^{2}$ „Realne projekty” - dotyczy konkretnych projektów. Uwzględniono przedstawienie realnych projektów, ponieważ jeden projekt czasami ogłaszany był raz, a czasem kilka razy. Dlatego konkretnych projektów jest mniej niż wszystkich wszczętych postępowań
} 
- według rodzajów: wszystkie wszczęte postępowania, realne projekty, zawarte umowy,

- według rodzaju podmiotu publicznego,

- według sektorów,

- według województw.

W pierwszej kolejności analizie poddano liczbę wszystkich postępowań w ramach partnerstwa publiczno-prywatnego, określanych jako wszystkie wszczęte postępowania, dalej liczbę realnych projektów oraz zawartych umów w latach 20092016 w Polsce. Dane zaprezentowano na Rysunku 1.

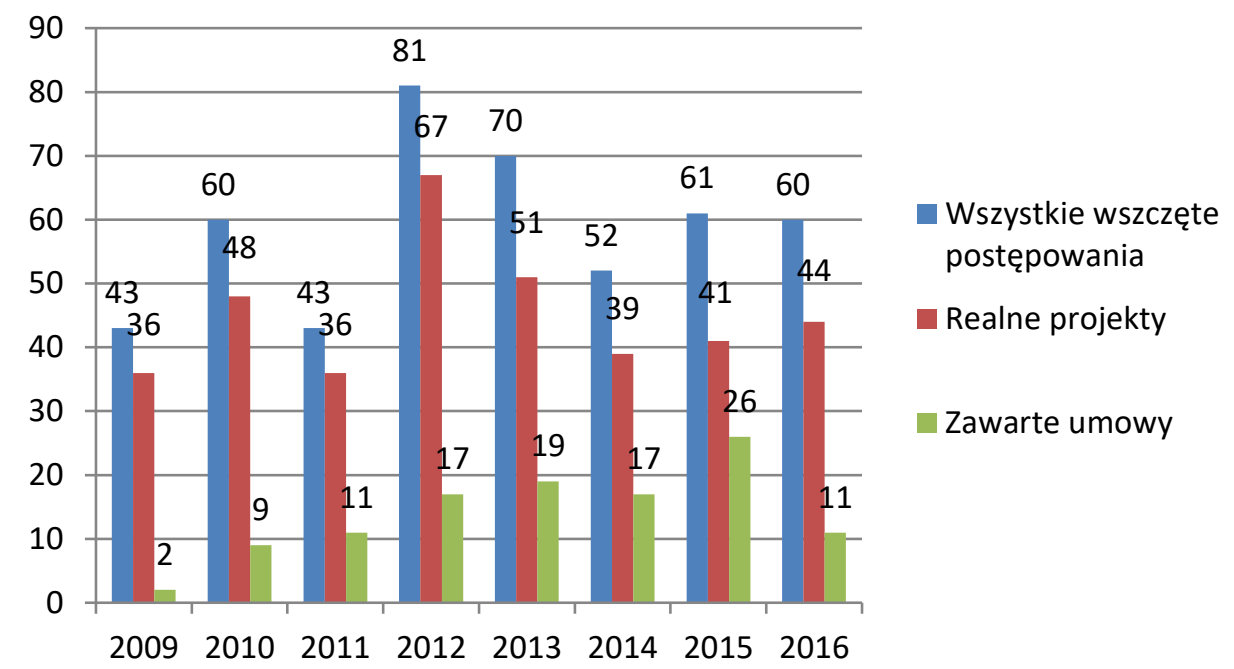

Rysunek 1. Liczba wszystkich wszczętych postępowań, realnych projektów oraz zawartych umów w ramach PPP w latach 2009-2016 w Polsce

Źródło: Opracowanie własne na podstawie (Analiza rynku PPP ... 2016, s. 90)

Na postawie danych zaprezentowanych na Rysunku 1 można zauważyć, że najwięcej wszystkich wszczętych postępowań (81) oraz realnych projektów (67) było w 2012 roku, natomiast zawartych umów (26) w roku 2015. Najmniej wszczętych postępowań (43) oraz realnych projektów (36) było w 2009 oraz w 2011 roku, natomiast zawartych umów (2) w roku 2009. Średnio w analizowanym okresie wszystkich wszczętych postępowań było 59, realnych projektów 45, a zawartych umów 14 .

Biorąc pod uwagę łączną liczbę wszystkich wszczętych postępowań, zauważyć można, że w latach 2009-2016 wynosiła ona 470, w tym nowych, niepowtarzających się projektów było około $70 \%$ (362). Z danych tych zatem wynika, że niektóre projekty ogłaszane były kilka razy. W analizowanym okresie zawarto 122 umowy (stanowiły $25,96 \%$ wszczynanych postępowań), z tego przed ich zakończeniem rozwiązanych było 7, natomiast niezrealizowanych 3 . Warto zauważyć, że najwięcej umów podpisywano w latach 2012-2015. Pozytywne doświadczenia, zdobyta wiedza i umiejętności spowodowały, że podmioty publiczne przygotowały ofertę współpracy 
bardziej odpowiadającą podmiotom prywatnym, co przełożyło się liczbę zawieranych umów w ostatnich latach.

W analizowanym okresie spośród wszystkich wszczynanych postępowań 46 jest w toku (projekty będące na etapie procedury przetargowej, które mogą zakończyć się podpisaniem umowy), natomiast unieważnionych zostało około 300. Postępowania w toku dotyczą zwłaszcza ostatnich lat: w 2015 - 11, natomiast w $2016-28$. Z poprzednich lat na różnym etapie przetargu pozostało ich 7 (Analiza rynku PPP... 2016, s. 9).

Tabela 3. Wszystkie wszczęte postępowania, realne projekty oraz zawarte umowy w ramach PPP w Polsce w latach 2009-2016 z podziałem na rodzaj podmiotu publicznego

\begin{tabular}{|l|r|r|r|r|r|r|}
\hline \multicolumn{1}{|c|}{ Wyszczególnienie } & \multicolumn{2}{c|}{$\begin{array}{c}\text { Wszczęte } \\
\text { postępowania }\end{array}$} & \multicolumn{2}{c|}{$\begin{array}{c}\text { Realne } \\
\text { projekty }\end{array}$} & \multicolumn{2}{c|}{$\begin{array}{c}\text { Zawarte } \\
\text { umowy }\end{array}$} \\
\hline Gmina miejska & 146 & $31,06 \%$ & 114 & $31,49 \%$ & 32 & $28,57 \%$ \\
\hline Gmina wiejska & 81 & $17,23 \%$ & 59 & $16,30 \%$ & 23 & $20,54 \%$ \\
\hline Gmina miejsko-wiejska & 68 & $14,47 \%$ & 49 & $13,54 \%$ & 16 & $14,29 \%$ \\
\hline Urząd marszałkowski & 36 & $7,66 \%$ & 33 & $9,12 \%$ & 9 & $8,04 \%$ \\
\hline Spółka komunalna & 31 & $6,60 \%$ & 28 & $7,73 \%$ & 6 & $5,36 \%$ \\
\hline Jednostka budżetowa & 31 & $6,60 \%$ & 25 & $6,91 \%$ & 7 & $6,25 \%$ \\
\hline SP ZOZ & 17 & $3,62 \%$ & 10 & $2,76 \%$ & 3 & $2,68 \%$ \\
\hline Starostwo powiatowe & 18 & $3,83 \%$ & 13 & $3,59 \%$ & 3 & $2,68 \%$ \\
\hline Samorząd. instytucje kultury & 16 & $3,40 \%$ & 7 & $1,93 \%$ & 1 & $0,89 \%$ \\
\hline Inne & 8 & $1,70 \%$ & 7 & $1,93 \%$ & 4 & $3,57 \%$ \\
\hline Uczelnie & 6 & $1,28 \%$ & 6 & $1,66 \%$ & 2 & $1,79 \%$ \\
\hline Administracja rządowa & 5 & $1,06 \%$ & 5 & $1,38 \%$ & 5 & $4,46 \%$ \\
\hline Związek gmin & 4 & $0,85 \%$ & 4 & $1,10 \%$ & 1 & $0,89 \%$ \\
\hline Dzielnica & 2 & $0,43 \%$ & 1 & $0,28 \%$ & 0 & $0,00 \%$ \\
\hline Samorządowa osoba prawna & 1 & $0,21 \%$ & 1 & $0,28 \%$ & 0 & $0,00 \%$ \\
\hline SUMA & 470 & $100 \%$ & 362 & $100 \%$ & 112 & $100 \%$ \\
\hline
\end{tabular}

Źródło: Opracowanie własne na podstawie (Analiza rynku PPP... 2016, s. 14)

Współpraca w ramach PPP w badanym okresie występowała w różnych formach, zarówno jeżeli chodzi o postępowania, jak i zawarte umowy. Najczęściej wybieraną była koncesja na usługi oraz PPP w trybie prawa zamówień publicznych, dalej koncesja na roboty budowlane oraz PPP w trybie koncesji (Analiza rynku PPP... 2016, s. 24).

Współpracą w ramach PPP ze strony sektora publicznego były zainteresowane różne podmioty, co przedstawiono w Tabeli 3. Na podstawie przedstawionych danych (Tabela 3) można stwierdzić, że najwięcej ofert współpracy w ramach PPP przygotowały, a także najwięcej umów zawarły jednostki samorządu terytorialnego różnych szczebli. Spośród nich wyróżniają się gminy, a szczególnie gminy miejskie 
(ponad 30\% (146) wszystkich ogłoszonych postępowań, w tym oryginalnych projektów było 114, podpisały również najwięcej umów (32)).

Formuła PPP w Polsce w latach 2009-2016 była wykorzystywana do realizacji różnych zadań publicznych, co przedstawiono na Rysunku 2.

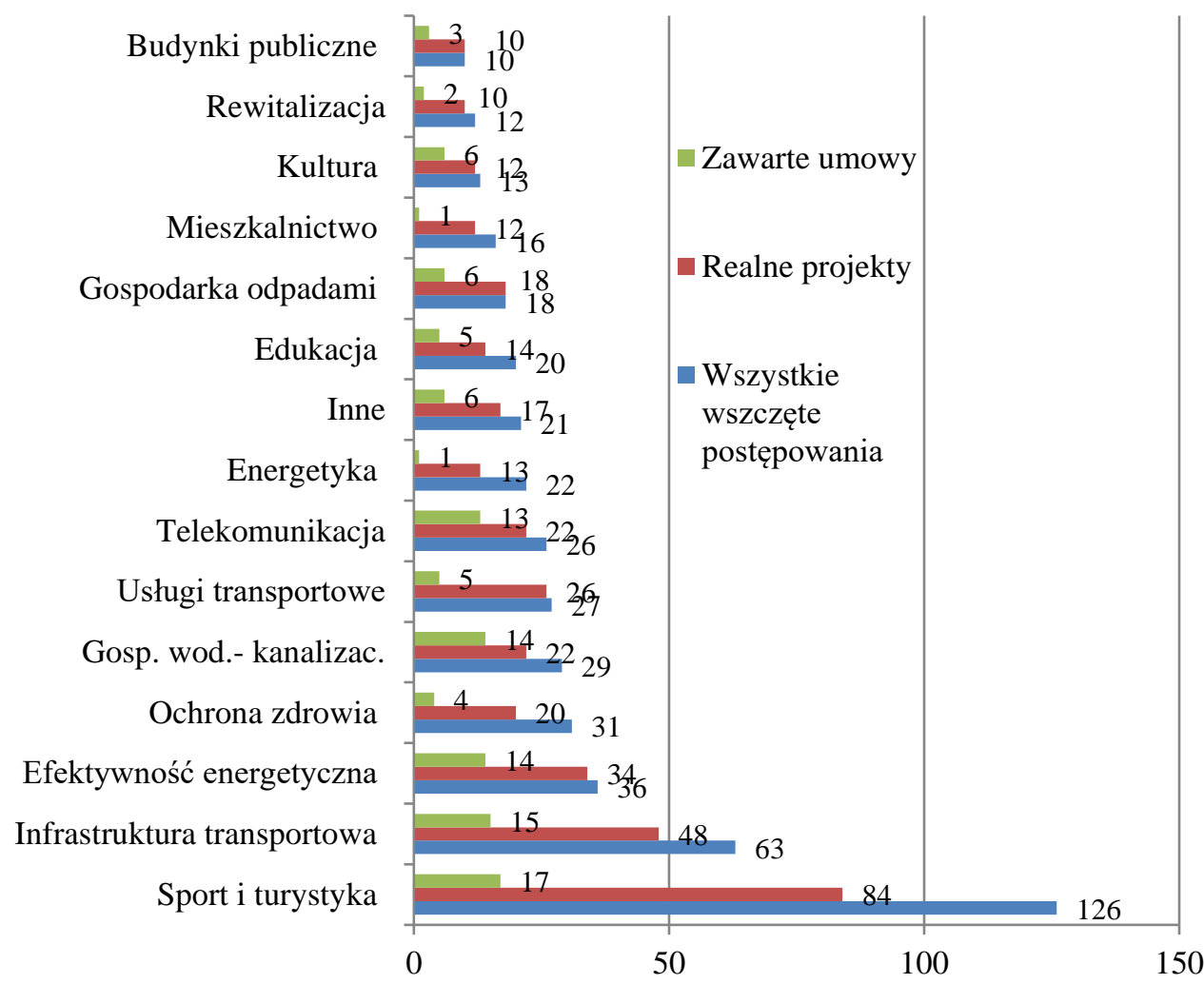

Rysunek 2. Struktura sektorowa krajowego rynku PPP - liczba wszystkich wszczętych postępowań, realnych projektów, zawartych umów w latach 2009-2016

Źródło: Opracowanie własne na podstawie (Analiza rynku PPP... 2016, s. 10)

W Polsce najwięcej ogłoszonych projektów PPP dotyczyło sportu i turystyki (127, co stanowiło $27 \%$ wszystkich postępowań). Duża część z tych projektów była ogłaszana kilkakrotnie. Skuteczność zawarcia umów w tym zakresie była niska $(13,5 \%)$ - tylko 17 umów. Kolejnymi sektorami, w których ogłaszano dużo projektów, były: infrastruktura transportowa $(13,4 \%)$, dalej efektywność energetyczna $(8 \%)$, ochrona zdrowia $(6,6 \%)$, gospodarka wodno-kanalizacyjna $(6,2 \%)$, usługi transportowe $(5,7 \%)$, telekomunikacja $(5,5 \%)$ i inne.

Najwięcej umów podpisano w sektorach: sport i turystyka, infrastruktura transportowa, efektywność energetyczna, gospodarka wodno-kanalizacyjna oraz telekomunikacja. 
Partnerstwo publiczno-prywatne w ujęciu regionalnym zaprezentowano w Tabeli 4.

Tabela 4. Wszystkie wszczęte postępowania, realne projekty oraz zawarte umowy w ramach PPP w Polsce w latach 2009-2016 z podziałem na województwa

\begin{tabular}{|c|c|c|c|c|c|c|}
\hline Województwa & $\begin{array}{r}\text { Wszy } \\
\text { wsz } \\
\text { postęp }\end{array}$ & $\begin{array}{l}\text { tkie } \\
\text { ęte } \\
\text { wania }\end{array}$ & & & $\begin{array}{l}\text { Zaw } \\
\text { um }\end{array}$ & $\begin{array}{l}\text { rte } \\
\text { wy }\end{array}$ \\
\hline Mazowieckie & 79 & $16,81 \%$ & 58 & $16,02 \%$ & 20 & $17,86 \%$ \\
\hline Małopolskie & 68 & $14,47 \%$ & 49 & $13,54 \%$ & 11 & $9,82 \%$ \\
\hline Dolnośląskie & 44 & $9,36 \%$ & 31 & $8,56 \%$ & 10 & $8,93 \%$ \\
\hline Śląskie & 41 & $8,72 \%$ & 37 & $10,22 \%$ & 18 & $16,07 \%$ \\
\hline Wielkopolskie & 33 & $7,02 \%$ & 30 & $8,29 \%$ & 10 & $8,93 \%$ \\
\hline Pomorskie & 32 & $6,81 \%$ & 24 & $6,63 \%$ & 12 & $10,71 \%$ \\
\hline Kujawsko-pomorskie & 27 & $5,74 \%$ & 18 & $4,97 \%$ & 3 & $2,68 \%$ \\
\hline Warmińsko-mazurskie & 27 & $5,74 \%$ & 16 & $4,42 \%$ & 7 & $6,25 \%$ \\
\hline Świętokrzyskie & 19 & $4,04 \%$ & 19 & $5,25 \%$ & 3 & $2,68 \%$ \\
\hline Lubelskie & 19 & $4,04 \%$ & 16 & $4,42 \%$ & 2 & $1,79 \%$ \\
\hline Opolskie & 18 & $3,83 \%$ & 17 & $4,70 \%$ & 3 & $2,68 \%$ \\
\hline Podkarpackie & 16 & $3,40 \%$ & 15 & $4,14 \%$ & 3 & $2,68 \%$ \\
\hline Lubuskie & 15 & $3,19 \%$ & 9 & $2,49 \%$ & 3 & $2,68 \%$ \\
\hline Zachodniopomorskie & 14 & $2,98 \%$ & 12 & $3,31 \%$ & 5 & $4,46 \%$ \\
\hline Podlaskie & 11 & $2,34 \%$ & 5 & $1,38 \%$ & 1 & $0,89 \%$ \\
\hline Łódzkie & 7 & $1,49 \%$ & 6 & $1,66 \%$ & 1 & $0,89 \%$ \\
\hline SUMA & 470 & $100 \%$ & 362 & $100 \%$ & 112 & $100 \%$ \\
\hline
\end{tabular}

Źródło: Opracowanie własne na podstawie (Analiza rynku PPP... 2016, s. 16)

Na podstawie danych z Tabeli 4 można zauważyć duże rozbieżności w zakresie wszystkich ogłaszanych postępowań, nowych projektów oraz zawartych umów w ramach PPP w poszczególnych województwach. Najwięcej projektów ogłoszono w regionie mazowieckim oraz małopolskim. Dalej w dolnośląskim oraz śląskim. Najmniej w łódzkim oraz podlaskim.

Analizując PPP w Polsce, można zauważyć dominację projektów o małej wartości (mniej niż $5 \mathrm{mln}$ zł). Jest to związane przede wszystkim z rodzajem podmiotów publicznych biorących udział w ww. współpracy, czyli z podmiotami szczebla lokalnego. Wartość rynku PPP w Polsce przedstawia się następująco: 
- wszystkie wszczęte postępowania - około 19,1 mld zł netto ${ }^{3}$,

- realne projekty - blisko $16105202574 \mathrm{zł}$ netto ${ }^{4}$,

- zawarte umowy - 5601994 248,43 zł brutto (Analiza rynku PPP... 2016, s. 17-18, 31).

\section{Studium przypadku - porównanie koncesji na budowę i utrzymanie wiat przystankowych w Warszawie i Krakowie}

Projekt pt. „Koncesja na budowę i utrzymanie wiat przystankowych oraz innych elementów wyposażenia" w Warszawie zakłada wykonanie ok. 625 wiat przystankowych, które zostaną dostarczone w oparciu o projekt tzw. „konkursowy” wskazany przez koncesjodawcę, z tym zastrzeżeniem, że w obszarach objętych nadzorem konserwatorskim (oznaczonych na mapie lokalizacji wiat przystankowych) koncesjonariusz będzie mógł zamiast projektu „konkursowego” zastosować projekt tzw. „konserwatorski”. Ponadto projekt zakłada zaprojektowanie i wykonanie ok. 955 wiat, które zostaną wykonane w oparciu o projekt własny koncesjonariusza przygotowany na podstawie wytycznych koncesjodawcy. Następnie zadaniem partnera prywatnego będzie utrzymanie wiat.

Przedmiotem drugiego z analizowanych projektów - „Koncesji na modernizację infrastruktury przystankowej poprzez wymianę wiat przystankowych oraz budowę zadaszeń w nowych lokalizacjach" w Krakowie - jest zaprojektowanie i budowa wiat przystankowych. Zadaniem koncesjonariusza jest demontaż starych wiat i zamontowanie nowych $\mathrm{w}$ miejsce zdemontowanych zadaszeń oraz w nowych lokalizacjach, podłączenie wiat do sieci elektrycznej i utrzymanie ich do końca umowy.

Obydwa projekty realizowane są $\mathrm{w}$ formule partnerstwa publiczno-prywatnego w oparciu o ustawę o koncesji na roboty budowlane lub usługi, z udziałem tego samego partnera prywatnego - AMS SA. Podmiotami publicznymi są odpowiednio: Urząd Miasta Stołecznego Warszawy oraz Zarząd Infrastruktury Komunalnej i Transportu w Krakowie (ZIKiT). Podstawowe dane dotyczące obu koncesji zawiera Tabela 5.

Przedstawione w Tabeli 5 przedsięwzięcia realizowane są w sektorze infrastruktury transportowej. Wartości umów brutto klasyfikują je odpowiednio w grupach: średniej (50-100 mln) w Warszawie i małej $(20-50 \mathrm{mln})$ w Krakowie. Obecny (30.06.2017) status realizacji umowy - zarządzanie umową.

\footnotetext{
${ }^{3}$ Dla 36 z 470 wszystkich wszczętych postępowań nie oszacowano wartości (Analiza rynku PPP... 2016, s. 17).

${ }^{4}$ Dla 33 z 362 projektów nie oszacowano wartości (Analiza rynku PPP... 2016, s. 17).
} 
Tabela 5. Podstawowe charakterystyki badanych koncesji

\begin{tabular}{|l|c|c|}
\hline \multirow{2}{*}{ Wyszczególnienie } & \multicolumn{2}{|c|}{ Projekt } \\
\cline { 2 - 3 } & $\begin{array}{c}\text { Koncesja na budowę } \\
\text { i utrzymanie wiat przystan- } \\
\text { kowych w Warszawie }\end{array}$ & $\begin{array}{c}\text { Koncesja na budowę } \\
\text { i utrzymanie wiat przystan- } \\
\text { kowych w Krakowie }\end{array}$ \\
\hline $\begin{array}{l}\text { Data wszczęcia } \\
\text { postępowania }\end{array}$ & 18.05 .2010 & 11.06 .2014 \\
\hline Data zawarcia umowy & 18.12 .2013 & 29.10 .2014 \\
\hline Okres realizacji & $\begin{array}{c}108 \text { miesięcy } \\
(9 \text { lat) }\end{array}$ & $\begin{array}{c}250 \text { miesięcy } \\
\text { (20 lat i 10 miesięcy) }\end{array}$ \\
\hline Zakończenie projektu & 01.11.2022 & 11.08 .2029 \\
\hline Nakłady inwestycyjne & 98000000 zł & 45 405 000 zł \\
\hline Źródła finansowania & $\begin{array}{l}\text { Całość nakładów inwestycyj- } \\
\text { nych oraz kosztów eksploata- } \\
\text { cji ponosi partner prywatny }\end{array}$ & $\begin{array}{l}\text { Całość nakładów inwestycyj- } \\
\text { nych oraz kosztów eksploat- } \\
\text { acji ponosi partner prywatny }\end{array}$ \\
\hline $\begin{array}{l}\text { Wynagrodzenie part- } \\
\text { nera prywatnego }\end{array}$ & $\begin{array}{l}\text { Prawo do eksploatacji gablot } \\
\text { reklamowych zainstalowa- } \\
\text { nych na wiatach przystanko- } \\
\text { wych }\end{array}$ & $\begin{array}{l}\text { Prawo do pobierania opłat za } \\
\text { usługi świadczone w ramach } \\
\text { koncesji }\end{array}$ \\
\hline $\begin{array}{l}\text { Dofinansowanie } \\
\text { z funduszy unijnych }\end{array}$ & Nie & Nak \\
\hline $\begin{array}{l}\text { Korzystanie z doradz- } \\
\text { twa }\end{array}$ & Nie \\
\hline
\end{tabular}

Źródło: Opracowanie własne na podstawie (http://www.ppp.gov.pl/...)

Celem projektu opisanej wyżej koncesji w Warszawie była wymiana 1580 wiat przystankowych przy udziale inwestora prywatnego. Koncesjonariusz w zamian za nowe wiaty otrzymał prawo do korzystania $\mathrm{z}$ atrakcyjnych powierzchni reklamowych umieszczonych na przystankach (na wiatach zamontowano nośniki reklamowe). Jest to pierwszy projekt zrealizowany przez władze Warszawy, którego podstawą jest ustawa o koncesji na roboty budowlane lub usługi. Postępowanie koncesyjne zostało ogłoszone w maju 2010 roku przez Zarząd Transportu Miejskiego. W postępowaniu najkorzystniejszą ofertę złożyło konsorcjum firm AMS i Ströer ${ }^{5}$, z którym 18 grudnia 2013 r. podpisano umowę koncesji na 108 miesięcy. Zgodnie $\mathrm{z}$ harmonogramem wiaty przystankowe powstawały w ciągu 3 lat od dnia podpisania umowy (http://infrastruktura.um.warszawa.pl/...).

W przypadku Krakowa inwestycja w zakresie modernizacji wiat przystankowych realizowana na zasadach koncesji była drugą tego typu umową. Pierwsza umowa

\footnotetext{
${ }^{5}$ Spółka Ströer Polska postanowiła wycofać się z operacyjnego zaangażowania w realizację projektu. Powodem decyzji firmy był fakt, iż ostateczne warunki realizacji koncesji nie spełniały na satysfakcjonującym poziomie oczekiwań Grupy Ströer. Tym samym, zgodnie z umową zawartą przez obie spółki, Ströer - formalnie pozostając w konsorcjum - zrezygnował z udziału w operacyjnej części przedsięwzięcia, cedując na AMS prawa i obowiązki wynikające z kontraktu (zob.: http://ams.com.pl/...).
} 
koncesji na usługi dotyczyła prowadzenia działalności reklamowej na panelach zintegrowanych $\mathrm{z}$ wiatami przystankowymi na terenie Gminy Miejskiej Kraków (nr 623/ZIKiT/2012 z dnia 12.11.2012 r.) i objęła:

- zakres ilościowy - 34 konstrukcje,

- okres budowy wiat - 2013 rok,

- okres obowiązywania umowy - 15 lat,

- utrzymanie konstrukcji wiaty: słupy, szyby, ławki itp. - prywatny podmiot,

- prawny właściciel zadaszeń - GMK/ZIKiT,

- utrzymanie powierzchni peronów - GMK/ZIKiT,

- opłaty za reklamę - opłaty za zajęcie pasa drogowego ponoszone przez prywatny podmiot,

- zyski z tytułu umieszczania reklam w gablotach reklamowych - prywatny podmiot.

Druga umowa koncesji podpisana została przez władze Krakowa na roboty budowlane („Koncesja na modernizację infrastruktury przystankowej poprzez wymianę wiat przystankowych oraz budowę zadaszeń w nowych lokalizacjach" - nr 470/ ZIKiT/2014 z dnia 29.10.2014 r.). Umowa ta objęła (Urząd Miasta Krakowa 2017):

- wymianę konstrukcji wiat w 500 lokalizacjach (w latach 2015-2029) - 519 konstrukcji;

- wiaty w nowych lokalizacjach - 100 szt. (w latach 2015-2018 - po 25 szt./rok);

- wyposażenie zadaszeń - w większości podświetlane gabloty, liniówki, znaki oraz standardowe wyposażenie w kosze i ławki;

- obowiązek utrzymania wiat i partycypacji w kosztach sprzątania przystanków w lokalizacjach, w których na wiatach zamontowane będą gabloty reklamowe;

- odremontowanie i posadowienie w nowych lokalizacjach 125 szt. wiat zdemontowanych w ramach wymiany;

- okres obowiązywania umowy - 250 miesięcy (od terminu odbioru);

- prawny właściciel konstrukcji-GMK/ZIKiT;

- opłaty za reklamę - opłaty za zajęcie pasa drogowego ponoszone przez prywatny podmiot;

- zyski z tytułu umieszczania reklam w gablotach reklamowych - prywatny podmiot. Porównanie podziału ryzyk realizacji badanych inwestycji umożliwia Tabela 6.

Korzyści finansowe wynikające $\mathrm{z}$ ekspozycji reklam w wiatach przystankowych są jedyną formą wynagrodzenia koncesjonariusza. Miasto nie musi dofinansowywać przedsięwzięcia z własnego budżetu w żadnej formie.

W czasie trwania umowy koncesji wybrany partner prywatny odpowiada za pełne utrzymanie wiat, od sprzątania po ich konserwację i remonty. Ponadto koncesjonariusz ponosi opłaty administracyjne i ewentualnie inne opłaty, w tym koszty oświetlania wiat. Jego zadaniem jest także ubezpieczenie przystanków. 
Tabela 6. Podział ryzyk w badanych koncesjach

\begin{tabular}{|c|c|c|}
\hline & \multicolumn{2}{|c|}{ Projekt } \\
\hline Ryzyko & $\begin{array}{c}\text { Koncesja na budowę } \\
\text { i utrzymanie wiat przystanko- } \\
\text { wych } \\
\text { w Warszawie } \\
\end{array}$ & $\begin{array}{c}\text { Koncesja na budowę } \\
\text { i utrzymanie wiat przystanko- } \\
\text { wych } \\
\text { w Krakowie }\end{array}$ \\
\hline $\begin{array}{l}\text { Ryzyka } \\
\text { po stronie } \\
\text { publicznej }\end{array}$ & $\begin{array}{l}\text { Ryzyko związane } \mathrm{z} \text { wniesieniem } \\
\text { składnika majątkowego w stanie } \\
\text { prawnym i technicznym zdatnym do } \\
\text { realizacji umowy koncesji. }\end{array}$ & $\begin{array}{l}\text { Ryzyko udostępnienia koncesjona- } \\
\text { riuszowi infrastruktury zaangażo- } \\
\text { wanej w realizację umowy. }\end{array}$ \\
\hline $\begin{array}{l}\text { Ryzyka } \\
\text { po stronie } \\
\text { prywatnej }\end{array}$ & $\begin{array}{l}\text { - } \\
\text { - } \quad \text { Ryzykyko budowy. } \\
\text { i utrzymaniem przedmiotu kon- } \\
\text { cesji (odśnieżanie jest po stronie } \\
\text { koncesjodawcy) oraz całkowite } \\
\text { ryzyko popytu. } \\
\text { - } \\
\text { Partner odpowiada za ryzyko } \\
\text { dewastacji. }\end{array}$ & $\begin{array}{l}\text { - } \text { Ryzyko budowy. } \\
\text { - Ryzyko eksploatacji oraz utrzy- } \\
\text { mania wiat stale dostępnych dla } \\
\text { podróżnych. } \\
\text { - } \\
\text { Ryzyko ekonomiczne - ryzyko } \\
\text { popytu na usługi świadczone } \\
\text { z wykorzystaniem infrastruktury } \\
\text { powstałej w ramach przedsię- } \\
\text { wzięcia. }\end{array}$ \\
\hline
\end{tabular}

Źródło: Opracowanie własne na podstawie (http://www.ppp.gov.pl/...)

Można wskazać następujące zalety umowy koncesji realizowanej w Warszawie (http://infrastruktura.um.warszawa.pl/...):

- zapewnienie przez koncesjonariusza finansowania, budowy i eksploatacji 1580 wiat przystankowych, $\mathrm{z}$ czego kilkaset ma unikalną i interesującą ikoniczną formę architektoniczną;

- uzyskanie przez władze miasta Warszawy majątku o wartości kilkudziesięciu milionów złotych bez wydatkowania środków z budżetu miasta;

- ponoszenie przez koncesjonariusza przez cały okres trwania kontraktu kosztów utrzymania, serwisowania i eksploatacji 1580 wiat, przez co miasto może każdego roku przeznaczyć zaoszczędzone środki, sięgające wielu milionów zł, na finansowanie podwyższania jakości usług $\mathrm{w}$ innych segmentach komunikacji publicznej;

- wpływ do budżetu miasta Warszawy stałej kwoty 1,5 mln zł rocznie (po zakończeniu fazy inwestycyjnej), którą wpłaca koncesjonariusz na poczet pokrycia kosztów sprzątania platform przystankowych, a także dodatkowej kwoty, która wynika z podziału zysku, zadeklarowanego przez koncesjonariusza w ofercie;

- znaczące przekształcenie obrazu reklamy zewnętrznej w Warszawie w kierunku zmniejszania formatów reklamowych i uwalniania krajobrazu od dominacji przeskalowanych reklam, dzięki wprowadzeniu przez koncesjonariusza ok. 3000 gablot reklamowych, harmonijnie zintegrowanych z elementami wyposażenia ulicy. 
Podobne korzyści wystąpiły w przypadku realizacji umowy koncesji w Krakowie. Władze miasta dostrzegły zalety formuły PPP i obecnie (w 2017 roku) ZIKiT przygotowuje postępowanie w celu zawarcia drugiej koncesji na wymianę wiat nieobjętych poprzednią umową. Liczba wiat i inne szczegóły będą znane dopiero po wyłonieniu koncesjonariusza. Wymiana ma jednak odbyć się na takich warunkach jak obecna, czyli bez kosztów dla miasta i z obowiązkiem utrzymywania obiektów w zamian za reklamę w gablocie na przystankach. Nowa koncesja na roboty budowlane pn. „Koncesja na modernizację infrastruktury przystankowej poprzez wymianę wiat przystankowych oraz budowę zadaszeń w nowych lokalizacjach - Etap II" ma być realizowana w latach 2017-2020. Wymiana ma odbyć się na takich warunkach jak obecna, czyli bez kosztów dla miasta i z obowiązkiem utrzymywania obiektów w zamian za reklamę w gablotach na przystankach (http://krakow.pl/...).

\section{Podsumowanie}

Partnerstwo publiczno-prywatne od wielu lat jest popularnym tematem i punktem programów politycznych w Polsce. Z drugiej strony dla władz lokalnych PPP jest obszarem trudnym, nierozpoznanym, także z uwagi na obawy przed sankcjami, zarzuty powiązań z podmiotami prywatnymi, procedurami przetargowymi itp. (Rutkowski 2010, s. 310-311). Korzyści ze współpracy w formie PPP w zakresie świadczenia usług przez samorządy terytorialne są bezsporne. Współpraca z podmiotami prywatnymi umożliwia rozwój infrastruktury bez obciążania długiem budżetów lokalnych. PPP może być także realizowane na poziomie rządowym, jednak ze względu na specyfikę zadań samorządów gminnych to na tym poziomie zarządzania ten typ współpracy występuje najczęściej (Ławińska, Wolniakowska 2014, s. 9193).

W Polsce w latach 2009-2016 wzrosło zainteresowanie współpracą między sektorem publicznym a prywatnym, jednak był to wzrost powolny. W badanym okresie ogłoszono 470 wszystkich postępowań dotyczących partnerstwa publiczno-prywatnego, z tego nowych projektów było około 70\%. Podpisano łącznie 122 umowy, co stanowiło $25,96 \%$ wszczynanych postępowań. Niektóre postępowania nadal trwają, więc podpisanych umów może być więcej. Największa liczba podpisanych umów była w latach 2012-2015.

Zaprezentowane przykłady współpracy w formie koncesji w obszarze infrastruktury transportowej (komunikacji miejskiej) potwierdzają zalety realizacji inwestycji infrastrukturalnych na zasadach partnerstwa publiczno-prywatnego. Podkreślić należy, że zadania własne miasta nie zostały sprywatyzowane, proces prywatyzacji dotyczył jedynie ich wykonania. Pozytywne jest także to, iż władze Warszawy i Krakowa zrozumiały, że ciąży na nich obowiązek organizowania i regulowania usług, a nie ich realizowanie.

Obecnie w Polsce urzeczywistniany jest projekt pt. „Rozwój partnerstwa publiczno-prywatnego w Polsce”, współfinansowany ze środków Europejskiego Funduszu Społecznego, w ramach Programu Operacyjnego Wiedza Edukacja Rozwój na lata 2014-2020. Głównym celem projektu jest podniesienie kwalifikacji pracowników administracji publicznej w zakresie partnerstwa publiczno- 
-prywatnego. Projekt oferuje pakiet bezpłatnych działań, np.: szkoleń, warsztatów, wizyt, misji studyjnych, debat. Efektem realizacji tego projektu będą wytyczne dotyczące realizacji projektów PPP oraz bezpłatny specjalistyczny kwartalnik poświęcony PPP.

Perspektywy partnerstwa publiczno-prywatnego przedstawiają się różnie, w zależności od obszaru usług komunalnych. Stabilne przepisy prawa regulujące PPP mogą być w przyszłości impulsem do rozwoju współpracy między sektorami publicznym i prywatnym. Pozytywne przykłady zarządzania zadaniami publicznymi, w których wykorzystuje się współpracę w ramach PPP, mogą stanowić przesłanki do zastosowania tej formuły współpracy przez inne podmioty. Prócz tego podmioty, które już podjęły się tego typu partnerstwa, zdobyły wiedzę i umiejętności, które mogą w przyszłości wykorzystać, realizując kolejne umowy w tym zakresie. Można zatem domniemywać, że w najbliższej przyszłości zainteresowanie PPP w Polsce powinno wzrosnąć bądź pozostać na takim samym poziomie.

\section{Literatura}

1. Analiza rynku PPP za okres od 2009 r. do 31 grudnia 2016 r. (2016), Ministerstwo Rozwoju, Departament Partnerstwa Publiczno-Prywatnego, Warszawa, http://www.ppp.gov.pl/ Aktualnosci/Documents/Analiza_rynku_PPP_31_12_2016.pdf (dostęp: 10.05.2017).

2. Brzozowska K. (2006), Partnerstwo publiczno-prywatne. Przesłanki, możliwości, bariery, CeDeWu, Warszawa.

3. Gawroński H. (2010), Zarzadzanie strategiczne w samorządach lokalnych, Wolters Kluwer, Warszawa.

4. http://ams.com.pl/o-firmie/aktualnosci/konsorcjum-ams-str-er-podpisalo-umowe-koncesjina-wiaty-w-warszawie (dostęp: 10.10.2017).

5. http://krakow.pl/aktualnosci/211811,1912,komunikat,stare_wiaty_przystankowe_do_wymiany.html (dostęp: 05.09.2017).

6. http://www.ppp.gov.pl/Aktualnosci/Documents (dostęp: 20.09.2017).

7. Kołodziej-Hajto M. (2015), Partnerstwo publiczno-prywatne jako narzędzie nowoczesnego zarzadzania organizacjami publicznymi, „Studia Ekonomiczne. Zeszyty Naukowe Uniwersytetu Ekonomicznego w Katowicach", nr 224, s. 51-60.

8. Łakomy M. (2012), Istota i rozwój rynku partnerstwa publiczno-prywatnego w Polsce, „Zeszyty Naukowe Uniwersytetu Szczecińskiego. Studia i Prace Wydziału Nauk Ekonomicznych i Zarządzania", nr 30, s. 65-77.

9. Ławińska O. (2011), Partnerstwo publiczno-prywatne jako forma finansowania gminnych inwestycji infrastrukturalnych, [w:] Ławińska O., Okręglicka M. (red.), Finansowe aspekty funkcjonowania przedsiębiorstw w XXI wieku, Wydawnictwo Politechniki Częstochowskiej, Częstochowa, s. 37-55.

10. Ławińska O., Wolniakowska K. (2014), Rozwój partnerstwa publiczno-prywatnego w Polsce ze szczególnym uwzględnieniem inwestycji infrastrukturalnych, [w:] Sipa M., Wolniakowska K. (red.), Zarządzanie współczesną organizacją, Sekcja Wydawnictw Wydziału Zarządzania Politechniki Częstochowskiej, Częstochowa, s. 91-103.

11. Łukomska-Szarek J. (2011), Finansowanie działalności rozwojowej samorzadów terytorialnych, „Zeszyty Naukowe Politechniki Śląskiej. Organizacja i Zarządzanie”, z. 59, s. 75-86.

12. Mikołajczyk D.P. (2010), Teoretyczne aspekty partnerstwa publiczno-prywatnego - zalety, wady, bariery rozwoju w Polsce oraz zwiazek z idea nowego zarządzania publicznego, prywatyzacji $i$ zamówień publicznych, „Acta Universitatis Lodziensis. Folia Oeconomica”, nr 243, s. 109-124. DOI: 11089/485 
13. Raport rynku PPP. Ocena obecnego stanu i perspektyw finansowego zaangażowania sektora prywatnego i publicznego $w$ rozwój partnerstwa publiczno-prywatnego w Polsce (2013), Warszawa, http://www.mg.gov.pl/files/upload/19767/20131218_raport_Instytut_PPP.pdf (dostęp: 30.06.2017).

14. Rutkowski J. (2010), Partnerstwo publiczno-prywatne $w$ Polsce i jego funkcjonowanie na przyktadzie wybranych projektów, Wydawnictwo Uniwersytetu Łódzkiego, Łódź.

15. Skelcher Ch. (2005), Public-Private Partnerships and Hybridity, [w:] Ferlie E., Lynn L.E., Pollitt Ch. (eds.), The Oxford Handbook of Public Management, Oxford University Press, New York, s. 347-370. DOI: 10.1093/oxfordhb/9780199226443.003.0016

16. Urząd Miasta Krakowa (2017), http://www.bip.krakow.pl/?dok_id=85036 (dostęp: 12.09.2017).

17. http://infrastruktura.um.warszawa.pl/partnerstwo-publiczno-prywatneplanowane-i-realizowane-projekty-ppp-w-warszawie/budowa-i-eksploatacja (dostęp: 10.09.2017).

18. Ustawa z dnia 19 grudnia 2008 r. o partnerstwie publiczno-prywatnym (Dz.U. $2009 \mathrm{nr} 19$ poz. $100, \mathrm{z}$ późn. $z \mathrm{zm}$.).

19. Ustawa z dnia 21 października 2016 r. o koncesji na roboty budowlane lub usługi (Dz.U. 2016 poz. 1920 , z późn. zm.).

20. Ustawa z dnia 29 stycznia 2004 r. - Prawo zamówień publicznych (Dz.U. 2004 nr 19 poz. 177, z późn. zm.).

21. Zagożdżon B. (2004), Partnerstwo publiczno-prywatne jako zalecany przez UE system finansowania inwestycji, ,Samorząd Terytorialny”, nr 9, s. 39-48.

\title{
PUBLIC-PRIVATE PARTNERSHIP AS A TREND OF LOCAL GOVERNMENT'S TASK MANAGEMENT IN POLAND IN 2009-2016
}

\begin{abstract}
Public-private partnership is one of the forms of cooperation between public authorities, so that they can effectively manage public tasks. The aim of this article is to analyze and evaluate cooperation based on public-private partnership in Poland in 2009-2016 and to present an example application of this formula in transport infrastructure. The research shows that in Poland in 2009-2016 interest in cooperation between the public and private sectors increased, but it was a slow growth. When analyzing PPPs in Poland, the dominance of low-value projects can be noticed. The presented examples of cooperation in the form of a concession in the area of transport infrastructure (public transport) confirm the advantages of implementing infrastructure investments on the basis of public-private partnership.
\end{abstract}

Keywords: concession, management, public tasks, public-private partnership 